\title{
Persistent hypotony after primary trabeculectomy with mitomycin $\mathbf{C}$
}

\author{
Hipotonia persistente depois de trabeculectomia primária com mitomicina $C$
}

Viviane R.F. Guedes ${ }^{(1)}$

Ruthanne B. Simmons ${ }^{(2)}$

Helena M. Pakter ${ }^{(3)}$

Richard J. Simmons ${ }^{(4)}$

\section{SUMMARY}

Purpose: To describe the clinical findings and treatment modalities of persistent hypotony following primary trabeculectomy with mitomycin $\mathbf{C}$.

Methods: We retrospectively analyzed 9 eyes with persistent hypotony, which was defined as intraocular pressure less than or equal to $5 \mathrm{mmHg}$ for more than 2 months.

Results: Mean hypotony duration was 7.4 months (standard deviation (SD) \pm 6.7 months, range 2 to 23 months). Associated findings included choroidal detachment ( 2 eyes) and maculopathy ( 5 eyes). All patients who developed maculopathy were relatively young (mean age $=37$ years old, $S D \pm 16$, range 18 to 79 years). Treatments included bandaged contact lens, autologous blood injection, phacoemulsification, resuturing of the scleral flap, scleral patch graft, and Simmons' shell. After treatment, intraocular pressure (IOP) raised in all patients (mean final IOP $=11.1 \mathrm{mmHg}, \mathrm{SD} \pm \mathbf{3 . 5}$ ). On the first day of hypotony, the mean IOP was $3 \mathrm{mmHg}(\mathrm{SD} \pm 1.7)$. At the last follow up, visual acuity (VA) was unchanged in 3 eyes, worsened in 2 eyes (by 2 Snellen lines), and improved (by 1 to 4 Snellen lines) in 4 eyes. Of those eyes whose VA improved, 3 had undergone phacoemulsification.

Conclusion: Hypotony after trabeculectomy with mitomycin C can be reversed with possible improvement in vision.

Keywords: Glaucoma; Trabeculectomy; Mitomycin C; Hypotony.

From Schepens Eye Research Institute, Harvard Medical School, Boston, MA, USA.

(1) Ex-Glaucoma Research Fellow at Schepens Eye Research Institute, Harvard Medical School and New England Medical Center, Tufts University School of Medicine Boston, MA, USA; Post-graduate, doctorate level, at Glaucoma Department of São Paulo University - USP; Chief of Glaucoma Department at Benjamin Constant Institute, RJ.

(2) Associate Clinical Professor of Ophthalmology, Harvard Medical School, Boston, MA, USA.

(3) Glaucoma Research Fellow at New England Medical Center, Tufts University School of Medicine, Boston, MA, USA.

(4) Associate Clinical Professor of Ophthalmology, Harvard Medical School, Boston, MA, USA.

The authors have no financial interest in any product or equipment cited in this paper.

Address for correspondence: Clínica de Olhos Guedes. Av. das Américas, 500 - Bl. 03 - Barra da Tijuca Downtown. Rio de Janeiro (RJ) Cep 22640-102. Telefax: (0XX21) 492-1441.

\begin{abstract}
INTRODUCTION
The antimetabolite mitomycin $\mathrm{C}$ has become widely used as an adjunct medication for inhibiting fibroblast proliferation in glaucoma filtering procedures $^{1-3}$. Mitomycin $\mathrm{C}$ is an antibiotic isolated from streptomycin caespitosus $^{1-3}$. It shows antitumor activity and acts as an alkylating agent by inhibiting DNA and interfering with RNA transcription and protein synthesis ${ }^{1-3}$. Although excellent results in intraocular pressure (IOP) reduction have been reported with the use of intraoperative mitomycin $\mathrm{C}$, postoperative complications, including persistent hypotony, remain a problem ${ }^{2}$.

Although hypotony with intraocular pressure lower than or equal to $5 \mathrm{mmHg}$ can be compatible with good vision, in some cases hypotony has been associated with maculopathy and marked visual loss ${ }^{4-6}$. Dellaporta ${ }^{7}$, and later Gass ${ }^{8}$, described the retinal manifestations of hypotony, papilledema, chorioretinal folds, and changes in the retinal pigment epithelium. Persistent hypotony may cause permanent macular damage and cataract progression ${ }^{4,5,9-11}$. The management of hypotony is an increasingly impor-
\end{abstract}


tant topic and includes different treatment modalities such as: large diameter bandage contact lens (BCL), autologous blood injection (ABI), Simmons' shell, surgical revision of the bleb (resuturing of the scleral flap, or scleral patch graft), and/or phacoemulsification ${ }^{3,12}$.

In this paper we report our experiences in nine cases of persistent hypotony, which for this study we define as IOP less than or equal to $5 \mathrm{mmHg}$ for more than 2 months, following primary filtering surgery with mitomycin $\mathrm{C}$, and the treatment modalities used.

\section{PATIENTS AND METHODS}

All available records of patients with hypotony after primary trabeculectomy with mitomycin $\mathrm{C}$ were retrospectively analyzed. All the procedures were performed by two experienced ophthalmic surgeons (RJS and RBS) at Ophthalmic Consultants of Boston and Massachusetts Eye and Ear Infirmary from October 1992 to June 1997.

All patients who had persistent hypotony, which we defined as intraocular pressure less than or equal to $5 \mathrm{mmHg}$, with or without clinical symptoms, for more than 2 months, entered this study. For the purpose of this study, early hypotony was defined as hypotony occurring within 10 days after filtering surgery. The late onset of hypotony was defined as hypotony occurring 200 days after filtering surgery or greater.

The same technique was performed in all cases. A limbalbased conjunctival flap was prepared $10 \mathrm{~mm}$ from the corneoscleral limbus. After meticulous cauterization of the sclera, a pledget of $0.4 \mathrm{mg} / \mathrm{ml}$ mitomycin $\mathrm{C}$ was applied on the sclera for 3.5 minutes. The conjunctiva was irrigated with $180 \mathrm{~mL}$ of normal saline solution. A $3 \times 3 \mathrm{~mm}$ rectangular scleral flap was dissected, a paracentesis was performed, and the anterior chamber was refilled with balanced saline solution (BSS). A Descemet's punch was used to create a sclerotomy. An iridectomy was performed. The scleral flap was sutured tightly with five to seven 10-0 nylon sutures in order to maintain a deep anterior chamber.

If, in the surgeon's judgment, any of the individual sutures seemed to restrict the fluid more than another, this was noted in the patient's chart to aid in the selection of sutures for any possible future laser suture lysis ${ }^{13}$.

Tenon's layer was then closed with a running horizontal mattress 9-0 vicryl suture and the conjunctiva was closed with a 10-0 nylon suture using a BV-75 needle. The anterior chamber was reformed with BSS and the incision was checked for leaks with $2 \%$ fluorescein.

Patients were treated postoperatively with corticosteroids, antibiotics, and cycloplegic medications. During the early postoperative days, laser suture lysis was performed as needed in order to release resistance to outflow and lower the IOP.

The care in each case was individualized, and suture lysis was done based on the IOP and slit-lamp appearance of the bleb and anterior chamber. When possible, the laser sessions were delayed until the third postoperative day, and no more than one suture was lyzed per session.

Patients with persistent hypotony were treated with one or more of the following treatment modalities: application of a large diameter bandage contact lens (BCL) over the bleb, autologous blood injection into the bleb, Simmons' shell which consists of a rigid contact lens with a smooth raised platform at its periphery and vent holes centrally placed over the eye to tamponade aqueous humor flow, surgical revision of the bleb (with resuturing of the scleral flap, or scleral patch graft), and phacoemulsification.

Information regarding age at the onset of hypotony, sex, race, and type of glaucoma was recorded. Number of medications, visual acuity (VA) and intraocular pressure (IOP) were measured before and after surgery, as well as during the period of hypotony. The interval between filtering surgery and onset of hypotony, the duration of hypotony, the and presence of associated findings were also recorded.

In order to analyze these data we use descriptive statistical analysis.

\section{RESULTS}

Persistent hypotony occurred in 8 patients ( 9 eyes). All were Caucasian, 4 males and 4 females. There were 4 right eyes and 5 left eyes. The types of glaucoma were Juvenile ( 3 eyes), Congenital (1 eye), Inflammatory (1 eye), Pigmentary (1 eye), Pseudoexfoliation (1 eye), Low Tension (1 eye), and Primary Open Angle (1 eye) (Table 1). All patients were phakic. The mean age at the onset of hypotony was 54 years ( $\mathrm{SD} \pm 21$, range 18 to 79 years).

Mean IOP before surgery was $26.6 \mathrm{mmHg}$ ( $\mathrm{SD} \pm 8.8$ ). On the first day of hypotony, the mean IOP was $3 \mathrm{mmHg}(\mathrm{SD} \pm$ 1.7). IOP improved in all patients to a mean of $11.1 \mathrm{mmHg}$ $(\mathrm{SD} \pm 3.5)$ after treatment (Table 2).

The mean number of preoperative glaucoma drops was 3.3 $(\mathrm{SD} \pm 1.5)$, and postoperatively it was $0.89(\mathrm{SD} \pm 1.3)$. During the period of hypotony, all patients used hyoscine and phenylephrine 4 times per day, and the steroid dosage was decreased or eliminated.

\begin{tabular}{|lccc|}
\hline & \multicolumn{2}{c|}{ Table 1: Demographic characteristics } \\
Eye & Age & Sex & Type of Glaucoma \\
I & 18 & Female & Juvenile \\
II & 59 & Female & Inflammatory \\
III & 75 & Female & Low Tension \\
IV & 68 & Male & Primary Open Angle \\
V & 55 & Male & Pigmentary \\
VI & 44 & Male & Congenital \\
VII & 79 & Female & Pseudoexfoliative \\
VIII & 31 & Male & Juvenile \\
IX & 18 & Female & Juvenile \\
\hline
\end{tabular}




\begin{tabular}{|lccc|}
\hline \multicolumn{4}{|c|}{$\begin{array}{c}\text { Table 2: Intraocular pressure (IOP) in mmHg values before } \\
\text { trabeculectomy, at first hypotony day and at last follow-up }\end{array}$} \\
Eye & $\begin{array}{c}\text { IOP Pre } \\
\text { Operative }\end{array}$ & $\begin{array}{c}\text { IOP First } \\
\text { Hypotony Day }\end{array}$ & $\begin{array}{c}\text { IOP Last } \\
\text { Follow-up }\end{array}$ \\
I & 33.0 & 2.0 & 8.0 \\
II & 36.0 & 0.0 & 17.0 \\
III & 16.0 & 2.0 & 7.0 \\
IV & 19.0 & 3.0 & 7.0 \\
V & 14.0 & 3.0 & 12.0 \\
VI & 35.0 & 5.0 & 10.0 \\
VII & 30.0 & 5.0 & 12.0 \\
VIII & 22.0 & 2.0 & 15.0 \\
IX & 34.0 & 5.0 & 12.0 \\
Mean & 26.6 & 3.0 & 11.1 \\
SD & 8.8 & 1.7 & 3.5 \\
\hline
\end{tabular}

The interval between filtering surgery and the onset of hypotony varied a lot among the patients (ranging from 1 to 720 days). While 5 eyes had an early onset of hypotony, 4 eyes had a late onset of hypotony. The mean duration of hypotony was 7.4 months (range 2 - 23 months, $\mathrm{SD} \pm 6.7$ ), and the mean follow-up was 29.7 months ( $\mathrm{SD} \pm 18.1$ ) (Table 3$)$.

None of the eyes developed bleb leak after surgery, and overfiltration was thought to be the basis of hypotony. Associated findings included choroidal detachment (2 eyes), and hypotonous maculopathy associated with a deep anterior chamber (5 eyes). All patients with maculopathy were relatively young (mean age $=37$ years, $S D \pm 16$ ), and three of these eyes were myopic (Table 4).

Besides adding cycloplegia, we reduced or eliminated corticosteroids in all patients in an effort to increase inflammatory reaction and raise IOP. Two eyes (I, II) were initially treated with a large diameter bandage contact lens (BCL). The use of a BCL in one of these patients (I) was enough to permanently increase the IOP from $2 \mathrm{mmHg}$ to $8 \mathrm{mmHg}$. The second patient (II) underwent phacoemulsification surgery in order to improve VA (preexistent cataract), and also to create eye inflammation. IOP was raised from $5 \mathrm{mmHg}$ to $17 \mathrm{mmHg}$.

Phacoemulsification alone was enough to reverse hypotony in 2 eyes (III and IV). In one eye (V) phacoemulsification, $\mathrm{BCL}$, autologous blood injection, and flap resuturing was required before IOP increased.

Autologous blood injection alone increased IOP in one eye (VI). Suprachoroidal fluid drainage followed by autologous blood injection increased IOP in 1 eye (VII).

One eye (VIII) had its IOP increased after it was initially treated with scleral patch graft followed by a Simmons' shell applied with a tight patch. Resuturing of scleral flap was done in one eye (IX) causing a postoperative increase in IOP. This eye had previous hypotony on the $19^{\text {th }}$ day after filtering surgery. It had been temporarily treated with a BCL. Eyes I and IX belong to the same patient (Table 4).

At the time of the last follow-up, visual acuity had im-

\begin{tabular}{|c|c|c|c|}
\hline \multicolumn{4}{|c|}{$\begin{array}{l}\text { Table 3: Interval between trabeculectomy and onset of } \\
\text { hypotony ( }{ }^{*} \text { in days), duration of hypotony and duration of } \\
\text { follow-up (** in months) }\end{array}$} \\
\hline Eye & $\begin{array}{c}\text { Interval } \\
\text { Filtering-Hypotony }\end{array}$ & $\begin{array}{l}\text { Duration of } \\
\text { Hypotony }\end{array}$ & $\begin{array}{l}\text { Duration of } \\
\text { Follow-up** }\end{array}$ \\
\hline I & 5.0 & 2.0 & 49.0 \\
\hline II & 1.0 & 2.3 & 18.0 \\
\hline III & 7.0 & 4.0 & 6.0 \\
\hline IV & 10.0 & 7.0 & 8.0 \\
\hline V & 200.0 & 23.0 & 32.0 \\
\hline VI & 540.0 & 7.0 & 34.0 \\
\hline VII & 5.0 & 5.0 & 18.0 \\
\hline VIII & 270.0 & 3.3 & 53.0 \\
\hline IX & 720.0 & 13.0 & 49.0 \\
\hline Mean & 195.3 & 7.4 & 29.7 \\
\hline SD & 269.2 & 6.7 & 18.1 \\
\hline
\end{tabular}

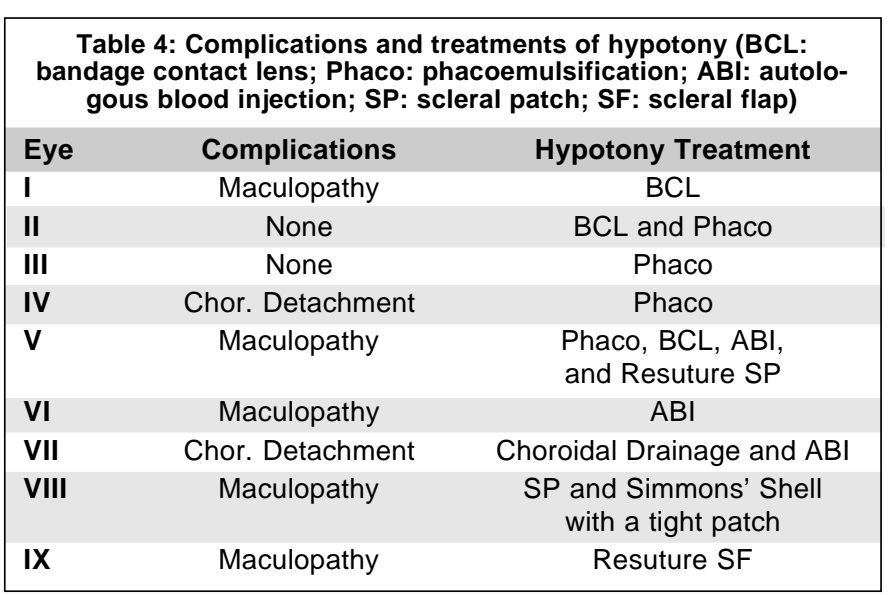

proved relative to acuity before surgery in 4 eyes (1-4 Snellen lines), was unchanged in 3 eyes, and worsened in 2 eyes ( 2 Snellen lines). Of the 4 eyes that had had an improvement in vision acuity, 3 had undergone phacoemulsification (Table 5).

\section{DISCUSSION}

Mitomycin $\mathrm{C}$ has been major advance in preventing filtration failure. There have been numerous studies describing success with mitomycin $\mathrm{C}$ in concentrations varying between $0.1 \mathrm{mg} / \mathrm{ml}$ and $0.5 \mathrm{mg} / \mathrm{ml}$ and exposure times varying from 1 to 5 minutes ${ }^{14-18}$. There are also many accounts of increased complications of mitomycin C filtering surgery including hypotony ${ }^{15,17,18}$. Hypotonous maculopathy has been associated with young patients and myopic patients. One possible explanation for the development of maculopathy might be reduced scleral rigidity. In this situation, retinal and choroidal folds occur in the patients ${ }^{3,19}$. In our study, all patients who developed maculopathy ( 5 eyes) were relatively young (mean age 37 ). Three of these eyes were myopic.

Gass ${ }^{8}$ suggested that hypotonous maculopathy may become 


\begin{tabular}{|lccc|}
\hline \multicolumn{5}{|c|}{$\begin{array}{c}\text { Table 5: Visual acuity (VA) before trabeculectomy, during } \\
\text { hypotony, and at last follow-up }\end{array}$} \\
Eye & $\begin{array}{c}\text { VA Pre } \\
\text { Operative }\end{array}$ & $\begin{array}{c}\text { VA During } \\
\text { Hypotony }\end{array}$ & $\begin{array}{c}\text { VA Last } \\
\text { Follow-up }\end{array}$ \\
& $20 / 20$ & $20 / 30$ & $20 / 20$ \\
I & $20 / 30$ & $20 / 80$ & $20 / 25$ \\
II & $20 / 25$ & $20 / 70$ & $20 / 25$ \\
III & $20 / 50$ & $20 / 70$ & $20 / 40$ \\
IV & $20 / 70$ & $20 / 200$ & $20 / 30$ \\
V & $20 / 30$ & $20 / 50$ & $20 / 20$ \\
VI & $20 / 50$ & $20 / 80$ & $20 / 70$ \\
VII & $20 / 20$ & $20 / 200$ & $20 / 20$ \\
VIII & $20 / 60$ & $20 / 200$ & $20 / 80$ \\
IX & & &
\end{tabular}

permanent with prolonged hypotony. Some studies suggested an association of final visual acuity with duration of hypotony ${ }^{1,2}$. Although in this paper we do not study the correlation between final visual acuity and duration of hypotony, it is our impression that it is important to treat the eye within 1 to 2 months in order to avoid permanent damage from hypotony.

Early and late hypotony require different treatments. A BCL, Simmons' shell and anterior chamber reformation with viscoelastic seem to be more effective in the treatment of early hypotony. Autologous blood injection and surgical revision of the bleb (resuture of the scleral flap, or scleral patch graft) appear to be more effective when treating late onset hypotony.

The use of phacoemulsification as a treatment of hypotony remains in discussion. While some studies suggest the use of cataract extraction as a treatment option for hypotony ${ }^{4,12}$, other studies did not find phacoemulsification to be helpful ${ }^{10}$ or even describe hypotony as a complication of cataract extraction ${ }^{20}$. In the present study we found phacoemulsification alone to be enough to revert hypotony in two of the nine eyes.

In order to avoid hypotony after primary trabeculectomy with mitomycin $\mathrm{C}$, a careful surgical technique is necessary. Extra scleral flap sutures in combination with laser suture lysis may allow better control of postoperative filtration. The ideal mitomycin $\mathrm{C}$ concentration and time of exposure remains unknown and further investigation is necessary in order to improve the success rate while decreasing complications.

In our 9 eyes with hypotony secondary to overfiltration of this study, we were able to successfully treat and reverse the hypotony. However, success (as defined as IOP >5) did not necessarily always correlate with a return to better visual acuity.

Careful management of hypotony is necessary. Hypotony after trabeculectomy with mitomycin can be reversed with possible improvement in vision. Further investigation is necessary in order to evaluate visual prognosis and duration of hypotony.

\section{RESUMO}

Objetivo: Descrever os achados clínicos e as modalidades de tratamento da hipotonia persistente após trabeculectomia primária com mitomicina $C$.

Método: Foram retrospectivamente analisados 9 olhos com hipotonia persistente, a qual foi definida como pressão intra-ocular igual ou menor que $5 \mathrm{mmHg}$ por mais que 2 meses.

Resultado: Tempo médio de duração da hipotonia foi de 7.4 meses, desvio padrão \pm 6.7 meses. Complicações associadas à hipotonia incluíram descolamento de coróide (2 olhos), maculopatia (5 olhos). Todos os pacientes que desenvolveram maculopatia eram relativamente novos (idade media de 37 anos, desvio padrão \pm 16 ). Tratamentos incluíram lente de contato, injeção autóloga de sangue, facoemulsificação, re-sutura do retalho escleral, e concha de Simmons. Após tratamento, houve melhora da pressão intra-ocular (PIO) em todos os pacientes (média final da $P I O=11.1 \mathrm{mmHg}$, desvio padrão \pm 3.51 , média da PIO no $1^{\circ}$ dia $=3 \mathrm{mmHg}$, desvio padrão \pm 1.7$)$. Na última visita, a acuidade visual (AV) permaneceu constante em 3 olhos, piorou em 2 olhos ( piora de 2 linhas de Snellen). Houve melhora da AV em 4 olhos (1 a 4 linhas de Snellen). Foi realizada facoemulsificação em 3 olhos dentre aqueles em que houve melhora da acuidade visual.

Conclusão: Hipotonia pós-trabeculectomia com mitomicina $C$ pode ser reversível com possível melhora da visão.

Palavras-chave: Glaucoma; Trabeculectomia; Mitomicina C; Hipotonia.

\section{REFERENCES}

1. Costa VP, Wilson RP, Moster MR, Schmidt CM, Grandham S. Hypotony maculopathy following the use of topical mitomycin $\mathrm{C}$ in glaucoma filtration surgery. Ophthalmic Surg 1993;24:389-94.

2. Nuyts RMM, Felton PC, Pels E, Langerhorst CT, Geijssen HC, Grossinklaus HE, Greve EL. Histophathologic effects of mitomycin C after trabeculectomy in human glaucomatous eyes with persistent hypotony. Am J Ophthalmol 1994;118:225-37.

3. Suner IJ, Greenfield DS, Miller MP, Nicolela MT, Palmberg PF. Hypotonous maculopathy after filtering surgery with mitomycin C. Ophthalmology 1997;104:207-15.

4. Sibayan SA, Igarashi S, Kasahara N, Montenegro MH, Simmons RJ, Simmons $\mathrm{RB}$, Smith TJ. Cataract extraction as a means of treating posfiltration hypotony maculopathy. Ophthalmic Surg Lasers 1997;28:241-3.

5. Singh KS, Byrd S, Egbert PR, Budenz D. Risk of hypotony after primary trabeculectomy with antifibrotic agents in a black West African population. Glaucoma 1998;7:82-5.

6. Lamping K, Bellows AR, Hutchinson BT, Afran SI. Long term evaluation of initial filtration surgery. Ophthalmology 1986;93:91-101.

7. Dellaporta A. Fundus changes in postoperative hypotony. Am J Ophthalmol 1955;40:781-5.

8. Gass DM, Hypotony maculopathy. In: Bellows JG, ed. Contemporary Ophthalmology. Baltimore : Williams \& Wilkins, 1972;34.

9. Kolker AE, Kass MA, Rait JL. Trabeculectomy with releasable sutures. Arch Ophthalmol 1994;112:62-6.

10. Chen PP, Weaver YK, Budenz DL, Feuer WJ, Parrish RK. Trabeculectomy function after cataract extraction. Ophthalmology 1998;105:1928-35.

11. Liebman J, Rich R. Complications of glaucoma filtering surgery. In: Rich R, Shields MB, Krupin T eds. The Glaucomas. Baltimore: Mosby, 1996;1703-36.

12. Bellows AR. Postoperative management following filtration surgery. In: Epstein DL, Allingham RR, Schuman JS, eds. Chandler and Grant's Glaucoma, 4th ed. Baltimore: Williams \& Wilkins, 1997;538-50. 
13. Savage JA, Condon GP, Lytle RA, Simmons RJ. Lysis after trabeculectomy. Ophthalmology 1988;95:1631-37.

14. Jampel HD. Effect of brief exposure to mitomycin $\mathrm{C}$ on viability and profile ration of cultured human tenons capsule fibroblasts. Ophthalmology 1992;99:1471-76.

15. Neelakantan A, Rao BS, Vijaya L, Grandham SB, Krishnan N, Riya S, Murugeshan R. Effect of the concentration and duration of application of mitomycin C in trabeculectomy. Ophthalmic Surg 1994;25:612-5.

16. Nuyts RMM, Greve EL, Geijssen HC, Langerhorst CT. Treatment of hypotonous maculopathy after trabeculectomy with mitomycin C. Am J Ophthalmol 1994;118:322-31.
17. Shields MB, Scroggs MW, Sloop CM, Simmons RB. Clinical and histophathologic observations concerning hypotony after trabeculectomy with adjunctive mitomycin C. Am J Ophthalmol 1993;116:673-83.

18. Zacharia PT, Deppermann SR, Schuman JS. Ocular hypotony after trabeculectomy with mitomycin C. Am J Ophthalmol 1993;116: 314-26.

19. Stamper RL, McMenemy MG, Lieberman MF. Hypotonous maculopathy after trabeculectomy with subconjuntival 5-fluorouracil. Am J Ophthalmol 1992;114:544-53.

20. Vouri ML. Recurrent severe hypotony after cataract surgery in an eye with previous trabeculectomy. Cataract Refract Surg 1998;24:136-8.

\title{
I CONGRESSO BRASILEIRO DE LENTES DE CONTATO E CÓRNEA
}

\author{
12 a 14 de Abril de 2001 \\ OURO MINAS PALACE HOTEL \\ Belo Horizonte - MG
}

\author{
Promoção: Sociedade Brasileira de Lentes de Contato e Córnea - SOBLEC \\ Presidente de Honra: Adamo Lui Netto \\ Presidente: Nicomedes Ferreira Filho \\ Secretário: Joel Edmur Boteon \\ Tesoureira: Ana Luiza da S. Galeti Nehemy
}

Informações: Consult Comunicação e Marketing
Tel./Fax:
(31) 274-1550
e-mail:
comunica@consultcom.com.br
internet:
www.consultcom.com.br 